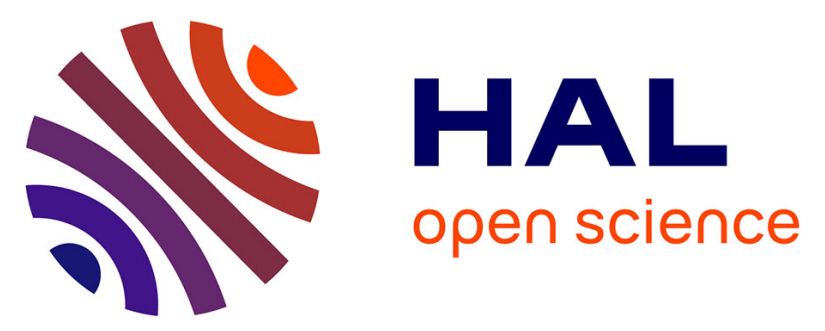

\title{
Assembly and Stacking of Flow-through Enzymatic Bioelectrodes for High Power Glucose Fuel Cells
}

Caroline Abreu, Yannig Nedellec, Andrew J. Gross, Olivier Ondel, François Buret, Alan Le Goff, Michael Holzinger, Serge Cosnier

\section{To cite this version:}

Caroline Abreu, Yannig Nedellec, Andrew J. Gross, Olivier Ondel, François Buret, et al.. Assembly and Stacking of Flow-through Enzymatic Bioelectrodes for High Power Glucose Fuel Cells. ACS Applied Materials \& Interfaces, 2017, 9 (28), pp.23836 - 23842. 10.1021/acsami.7b06717 . hal-01617973

\section{HAL Id: hal-01617973 https://hal.science/hal-01617973}

Submitted on 19 Nov 2020

HAL is a multi-disciplinary open access archive for the deposit and dissemination of scientific research documents, whether they are published or not. The documents may come from teaching and research institutions in France or abroad, or from public or private research centers.
L'archive ouverte pluridisciplinaire HAL, est destinée au dépôt et à la diffusion de documents scientifiques de niveau recherche, publiés ou non, émanant des établissements d'enseignement et de recherche français ou étrangers, des laboratoires publics ou privés. 


\title{
Assembly and Stacking of Flow-through Enzymatic Bioelectrodes for High Power Glucose Fuel Cells
}

\author{
Caroline Abreu, ${ }^{\dagger, \dagger}$ Yannig Nedellec, ${ }^{\dagger}$ Andrew J. Gross, ${ }^{\dagger}$ Olivier Ondel, ${ }^{\dagger}$ Francois Buret, ${ }^{\dagger}$ Alan Le Goff, ${ }^{*}{ }^{\dagger}$ \\ Michael Holzinger, ${ }^{*} \dagger$ and Serge Cosnier ${ }^{\dagger}$ \\ †Université Grenoble Alpes-CNRS, DCM UMR 5250, F-38000 Grenoble, France \\ "Université de Lyon, CNRS UMR 5005, Laboratoire Ampère 36 avenue Guy de Collongue, 69134 Ecully Cedex, France
}

\author{
Supporting Information
}

ABSTRACT: Bioelectrocatalytic carbon nanotube based pellets comprising redox enzymes were directly integrated in a newly conceived flow-through fuel cell. Porous electrodes and a separating cellulose membrane were housed in a glucose/oxygen biofuel cell design with inlets and outlets allowing the flow of electrolyte through the entire fuel cell. Different flow setups were tested and the optimized single cell setup, exploiting only $5 \mathrm{mmol} \mathrm{L}{ }^{-1}$ glucose, showed an open circuit voltage (OCV) of $0.663 \mathrm{~V}$ and provided $1.03 \pm 0.05$ $\mathrm{mW}$ at $0.34 \mathrm{~V}$. Furthermore, different charge/discharge cycles at $500 \Omega$ and $3 \mathrm{k} \Omega$ were applied to optimize long-term stability

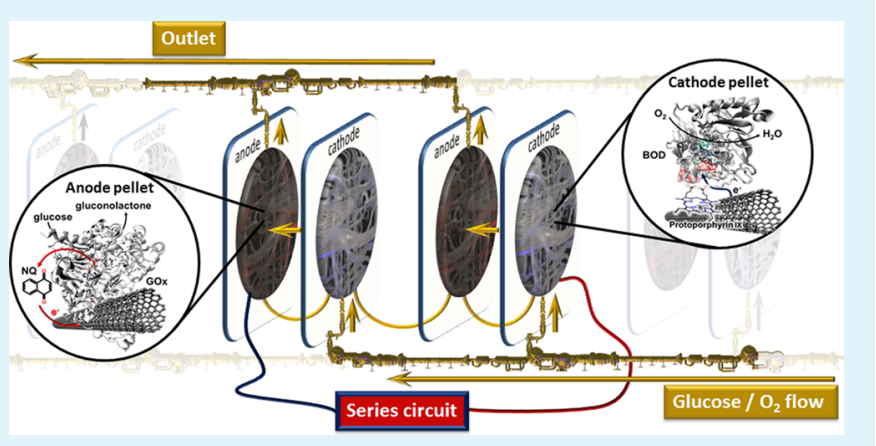
leading to $3.6 \mathrm{~J}(1 \mathrm{~mW} \mathrm{~h})$ of produced electrical energy after $48 \mathrm{~h}$. Under continuous discharge at $6 \mathrm{k} \Omega$, about $0.7 \mathrm{~mW} \mathrm{~h}$ could be produced after a $24 \mathrm{~h}$ period. The biofuel cell design further allows a convenient assembly of several glucose biofuel cells in reduced volumes and their connection in parallel or in series. The configuration of two biofuel cells connected in series showed an OCV of $1.35 \mathrm{~V}$ and provided $1.82 \pm 0.09 \mathrm{~mW}$ at $0.675 \mathrm{~V}$, and when connected in parallel, showed an OCV of $0.669 \mathrm{~V}$ and provided $1.75 \pm 0.09 \mathrm{~mW}$ at $0.381 \mathrm{~V}$. The presented design is conceived to stack an unlimited amount of biofuel cells to reach the necessary voltage and power for portable electronic devices without the need for step-up converters or energy managing systems.

KEYWORDS: biofuel cell, glucose, series and parallel stacks, enzymes, carbon nanotubes

\section{INTRODUCTION}

Fuel cell technology relies on the conversion of chemical energy into electrical energy and has gained much attention as an alternative power generator in the automotive sector. ${ }^{1}$ The fuel of choice for these applications is hydrogen but its high flammability represents a risk for end-users, requiring sophisticated security measures. ${ }^{2}$ Glucose is one of the most important energy sources of many living organisms and can be considered as a safe, easy-to-handle, and even edible fuel. The main difference compared to hydrogen fuel cells is that glucose biofuel cells (GBFC) convert glucose instead of hydrogen at the anode for power production while the principle of the electrocatalytic oxygen reduction at the cathode remains the same. One of the greatest challenges in GBFC research concerns the choice of the catalyst. Noble metal catalysts like platinum are not only expensive but also often inappropriate due to rapid poisoning issues and efficient activities only in acid and alkaline media. ${ }^{3,4}$ Biological catalysts (enzymes) are promising alternatives since most of them are operational at neutral $\mathrm{pH}$ and ambient temperature. ${ }^{5}$ Furthermore, enzymes have a unique selectivity which allows power production in complex media. In the case of glucose oxidase (GOx), this enzyme oxidizes glucose to gluconolactone removing two electrons which are transferred to the cofactor flavin adenine dinucleotide (FAD). The formed $\mathrm{FADH}_{2}$ usually regenerates by reducing oxygen to hydrogen peroxide which is commonly considered as an unwanted byproduct for biofuel cell applications. ${ }^{6}$ To avoid its production, electron mediators are used to regenerate $\mathrm{FADH}_{2}$ which clearly improve the electron transfer to the electrode. ${ }^{7-9}$ However, the use of such mediators does not totally prevent $\mathrm{H}_{2} \mathrm{O}_{2}$ production and in many cases a further enzyme (catalase) may be incorporated in bioanodes to convert $\mathrm{H}_{2} \mathrm{O}_{2}$ to water and oxygen. ${ }^{10}$ At the biocathode, multicopper enzymes like laccase and bilirubin oxidase (BOD) are promising candidates since these biocatalysts reduce oxygen to water in a four electron reduction and the catalytic site can be directly regenerated by the electrodes. ${ }^{11-13}$ With this background, GBFCs are envisioned to produce energy out of body fluids since they contain both glucose and oxygen as fuel and oxidant, respectively. ${ }^{14}$ As such, GBFCs offer the exotic prospect of providing an autonomous power supply for implantable electronic devices from the

Received: May 12, 2017

Accepted: June 28, 2017

Published: June 28, 2017 

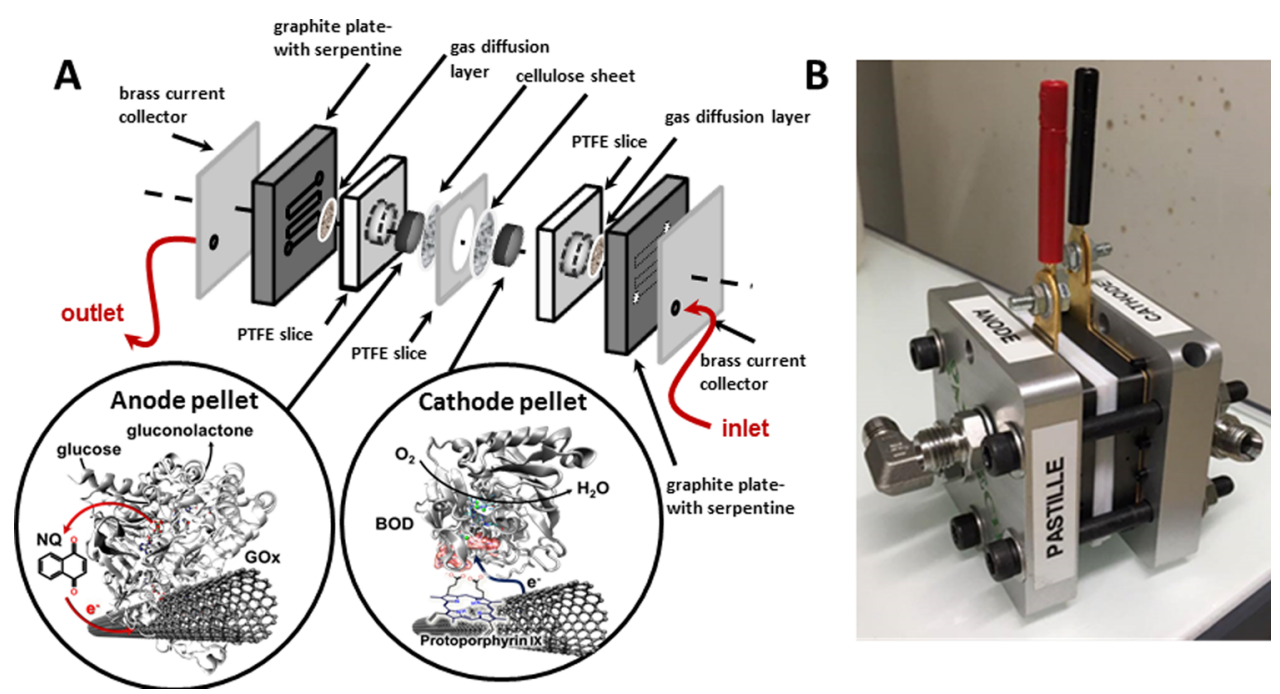

Figure 1. Scheme (A) and photo (B) of the flow-through cell used for one individual GBFC. The insets in the scheme represent the components used for the bioanode and the biocathode. The red arrows show the flow direction of the glucose solution.

human body. Even when the current densities are promising, the cell voltage of individual GBFCs is not high enough to run a device. Szczupak et al. implanted glucose biofuel cells in clams and connected three of them in parallel and in series for charging a capacitor which activated an electric motor to turn. ${ }^{15}$ MacVittie et al. connected two "cyborg" lobsters one year later and activated a watch for more than $1 \mathrm{~h}^{16}$ Several configurations were tested to connect two GBFCs in series in one lobster (in its back and in its claws) to reach the necessary voltage. However, the low impedance of the lobster's body tissues prevented realization of the desired voltage output. Since it is not realistic to connect two or more individual organisms for sufficient power to run devices, an appropriate design of GBFCs is necessary. Sakai et al. proposed already in 2009 a design with two stacked GBFCs, in a parallel setup, which doubled current densities using individualized inlets and outlets for glucose solutions and air, ${ }^{17}$ but this design is limited to the connection of only two biofuel cells. Miyake et al. used laminar bioelectrodes for a fructose biofuel cell with fructose containing hydrogels as separators and connected three biofuel cells in series. ${ }^{18}$ Here, the lack of a refueling system and issues concerning drying of the hydrogel led to reduced operational lifetime.

In this respect, the design of scalable and stackable GBFCs with optimized access for both glucose and oxygen is of particular importance. We have designed a novel flow-through concept leading to optimized power outputs, energy yields, and lifetimes. The flow of oxygen and glucose solutions was optimized in especially designed housings which allow the connection of several GBFCs in series and in parallel. While classic biofuel cell designs always privilege two electrodes in an electrolyte or a flow of solution between both electrodes, ${ }^{19-22}$ we present here the first example of an enzymatic fuel cell in which the electrolyte flows through the whole biofuel cell. This was possible by integrating a porous cathode and anode separated by a porous cellulose membrane. This system has many advantages in terms of ease of fabrication, flexibility, and potential microfabrication.

Furthermore, this system allows the easy fabrication of biofuel cells and their integration in more sophisticated circuits. Therefore, the work reported herein is dedicated to the power management of GBFCs to obtain sufficient power to run nomadic low-power devices like a timer or a watch without the need for capacitors or step up converters over long-term periods of several days.

\section{MATERIAL AND METHODS}

All reagents including glucose oxidase (GOx) from Aspergillus niger and catalase from bovine liver were purchased from Aldrich. Bilirubin oxidase (BOD) from Myrothecium verrucaria was obtained from Amano. Multiwalled carbon nanotubes (MWCNTs) were purchased from Nanocyl (>95\% purity, $10 \mathrm{~nm}$ diameter, $1.5 \mu \mathrm{m}$ length). The microporous GDL with $210 \mu \mathrm{m}$ of thickness, $8 \mathrm{~m} \Omega \mathrm{cm}^{2}$ of through plane electrical resistance and through plane air permeability of $70 \mathrm{~s}$, was purchased from Paxitech. The $100 \%$ cellulose membrane with 0.13 $\mathrm{mm}$ thickness and $64 \mathrm{~g} \mathrm{~m}^{-2}$ was purchased from FiltraTech. The graphoil came from Panasonic with $0.07 \mathrm{~mm}$ thickness and $1000 \mathrm{~W} / \mathrm{m}$ $\mathrm{K}$ thermic conductivity. Enzymes were stored at $-20{ }^{\circ} \mathrm{C}$. Distilled water was obtained by water purification to a resistivity of $15 \mathrm{M} \Omega \mathrm{cm}$ using a Millipore Ultrapure system. High purity oxygen and argon were obtained from Messer. Glucose solutions were left to mutarotate overnight to $\beta$-D-glucose prior to use.

For electrochemical characterization of the biofuel cell, the anode was set as the working electrode while the cathode was plugged as the counter-reference electrode. For half-cell testing, cyclic voltammograms (CVs) were recorded with the anode or cathode as the working electrode, a $\mathrm{Ag} / \mathrm{AgCl}$ (sat. $\mathrm{KCl}$ ) reference electrode and a $\mathrm{Pt}$ wire counter electrode. All experiments were conducted in Mc Ilvaine buffer $\mathrm{pH}$ 7. The biofuel cell was connected to the multichannel potentiostat Biologic VMP3 running EC-lab software 10.39. Polarization and power curves were measured after $30 \mathrm{~s}$ discharge. All the experiments were performed at room temperature.

Preparation of the Bioanode. The MWCNT pellets were obtained by soft grinding of a mixture of $100 \mu \mathrm{L}$ of distilled water, 5 $\mathrm{mg}$ of 1,4-naphthoquinone, $15 \mathrm{mg}$ of GOx from Aspergillus niger (174 $\left.\mathrm{U} \mathrm{mg}^{-1}\right), 10 \mathrm{mg}$ of catalase from bovine liver $\left(1600 \mathrm{U} \mathrm{mg}^{-1}\right)$ and 35 $\mathrm{mg}$ of MWCNTs. Catalase was used in combination with GOx in order to catalyze both the decomposition of hydrogen peroxide and the removal of oxygen at the bioanode. The homogeneous paste is then compressed in a hydraulic press to obtain a pellet with a $1.3 \mathrm{~cm}$ diameter and $2 \mathrm{~mm}$ thickness in a plexiglass holding, as opposed to our classical procedure where a free-standing pellet is obtained. ${ }^{10}$ A GDL disc was then connected to one side of the pellet to make the electrical connection with the graphite plate.

Preparation of the Biocathode. A similar procedure was employed using $15 \mathrm{mg}$ BOD from Myrothecium verrucaria (1.96 U $\mathrm{mg}^{-1}$ ) and $35 \mathrm{mg}$ of functionalized MWCNTs. The efficient 
immobilization and orientation of BOD on MWCNT electrodes by using $\pi$-stacked protoporphyrin IX as a direct electron-transfer promoter is used. ${ }^{12}$

Design of the Biofuel Cells. The biofuel cells were designed according to two configurations. First, the flow-through biofuel cell design was developed around a commercial Paxitech housing. It consists of a $5 \mathrm{~cm}^{2}$ test fuel cell with graphite bipolar plates and a serpentine gas flow design. Our purpose was the alternative utilization of the serpentine for solution and air flow rate management. A $3 \mathrm{~mm}$ thick PTFE slice was designed with a hole in the center having a 13 $\mathrm{mm}$ diameter. A microporous GDL was then placed at the backside of the PTFE to serve as the electron collector while assuring the diffusion of oxygen and the glucose solution. The CNT-enzyme pellet was compressed in the $13 \mathrm{~mm}$ hole onto the GDL. The open side of the pellet was then covered with a cellulose sheet which served as an effective electrolyte reservoir. A further PTFE of $127 \mu \mathrm{m}$ thickness with a $13 \mathrm{~mm}$ hole was placed in between the bioanode and the biocathode as a separator and to prevent any leakage. At the GDL backside of each bioelectrode, a graphite plate with engraved serpentines and inlet and outlet holes, as well as a brass plate for the final current collector, was pressed together to finalize the GBFC design. For standard operation, a peristaltic pump was used to circulate the aqueous solution with a constant $0.15 \mathrm{~mL} \mathrm{~min}^{-1}$ flow rate. A second biofuel cell design was developed in order to allow the easy fabrication of multiple biofuel cells, using easy-to-handle homemade Plexiglas elements. To provide a constant glucose flow within the cells, either a peristaltic pump or standard glucose perfusion bag, such as those found in hospitals, was explored.

\section{RESULTS AND DISCUSSION}

Principle and Performances of the Flow-through Biofuel Cell. A complete scheme of the biofuel cell design is displayed in Figure 1. Both the anode and the cathode were made according to our previously described procedure. ${ }^{8}$ Briefly, the glucose-oxidizing anode is composed of GOx and the mediator naphthoquinone confined in a CNT matrix. The mediator acts as an electron shuttle for the obtained electrons from the enzyme to the CNT electrode. Such mediation is unfortunately not quantitative as unwired GOx reacts by reduction of oxygen to hydrogen peroxide. Thus, catalase is added to consume a maximum amount of the enzymatically generated $\mathrm{H}_{2} \mathrm{O}_{2}$. The oxygen-reducing cathode is composed of protoporphyrin IX functionalized CNTs and BOD. Protoporphyrin IX has been shown to be an efficient electron transfer promoter leading to oriented immobilization of BOD and DET due to its similar structure to the natural substrate bilirubin. ${ }^{12}$ The required electrons for oxygen reduction are therefore directly supplied by the MWCNT matrix. The glucose solution flow was directed from the cathode to the anode to avoid inhibition of the biocathode by any remaining hydrogen peroxide not consumed by the catalase at the anode. Figure S1 in the Supporting Information (SI) displays CV curves corresponding to both the cathode and the anode.

Four flow setups were investigated based on the modular biofuel cell design shown in Figure 1. The different configurations and their associated polarization and power curves are depicted in Figure 2. The configuration A represents a simple biofuel cell in which each electrode is placed in its chamber. The GBFC exhibits an OCV of $0.65 \mathrm{~V}$ and delivers a maximum power output of $0.51 \pm 0.03 \mathrm{~mW}\left(0.38 \mathrm{~mW} \mathrm{~cm}{ }^{-2}\right.$, $1.9 \mathrm{~mW} \mathrm{~mL}^{-1}$, and $4.43 \mathrm{~mW} \mathrm{~g}^{-1}$ ) (in $5 \mathrm{mmol} \mathrm{L}^{-1}$ glucose in McIlvaine buffer at $\mathrm{pH}$ 7. For all other configurations, a porous cellulose membrane $(0.13 \mathrm{~mm}$ thickness) was employed in order to separate both electrodes, allow the flow of electrolyte, and minimize electrode distances while ensuring an easy-to-
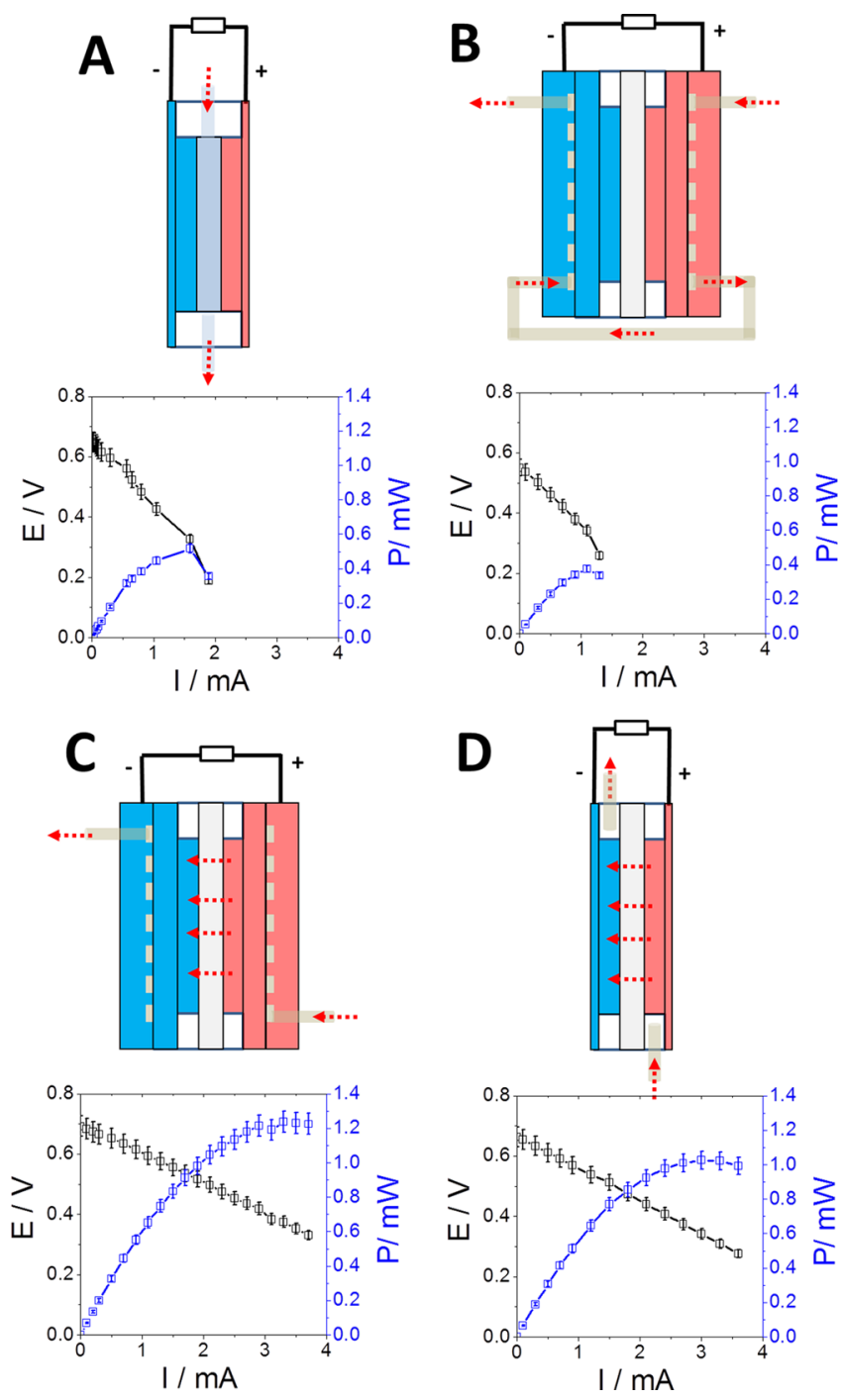

Figure 2. Schemes of the flow designs and corresponding measured performances (power profile (blue) and polarization curve (black)) for (A) the configuration of one biofuel cell where both bioelectrodes were simultaneously supplied with the glucose $/ \mathrm{O}_{2}$ solution; (B) the configuration with an external circuit flowing through the serpentines at the cathode to the serpentines at the anode; (C) the configuration with a glucose solution flowing from the cathode to the anode, passing through the cellulose membrane; and (D) the configuration with a complete flow-through from the cathode to the anode. Each point of the corresponding power profiles represents the value obtained after $30 \mathrm{~s}$ discharge between 0.1 and $3.7 \mathrm{~mA}$. All experiments were repeated 3 times under identical conditions.

made multilayer fabrication. The configuration $\mathrm{B}$ represents the GBFC with an external flow circuit of $5 \mathrm{mmol} \mathrm{L}^{-1}$ glucose flowing through the serpentines at the cathode to the serpentines at the anode. An OCV of $0.55 \mathrm{~V}$ with a maximum power output of $0.38 \pm 0.02 \mathrm{~mW}\left(0.28 \mathrm{~mW} \mathrm{~cm}{ }^{-2}, 1.39 \mathrm{~mW}\right.$ $\mathrm{mL}^{-1}$, and $3.27 \mathrm{~mW} \mathrm{~g}^{-1}$ ) at $0.33 \mathrm{~V}$ was reached. In configuration $\mathrm{C}$, the electrolyte outlet was removed from the cathode, while the inlet was removed from the anode. This allows the air saturated $5 \mathrm{mmol} \mathrm{L}{ }^{-1}$ glucose solution to flow from the cathode to the anode, passing through the cellulose membrane. The measured OCV of this setup is clearly increased and an improved maximum power output of 1.24 $\pm 0.06 \mathrm{~mW}\left(0.93 \mathrm{~mW} \mathrm{~cm}^{-2}, 4.58 \mathrm{~mW} \mathrm{~mL}^{-1}\right.$, and $10.76 \mathrm{~mW}$ $\left.\mathrm{g}^{-1}\right)$ at $0.375 \mathrm{~V}$ was obtained. The 3 -fold increase for this flow- 

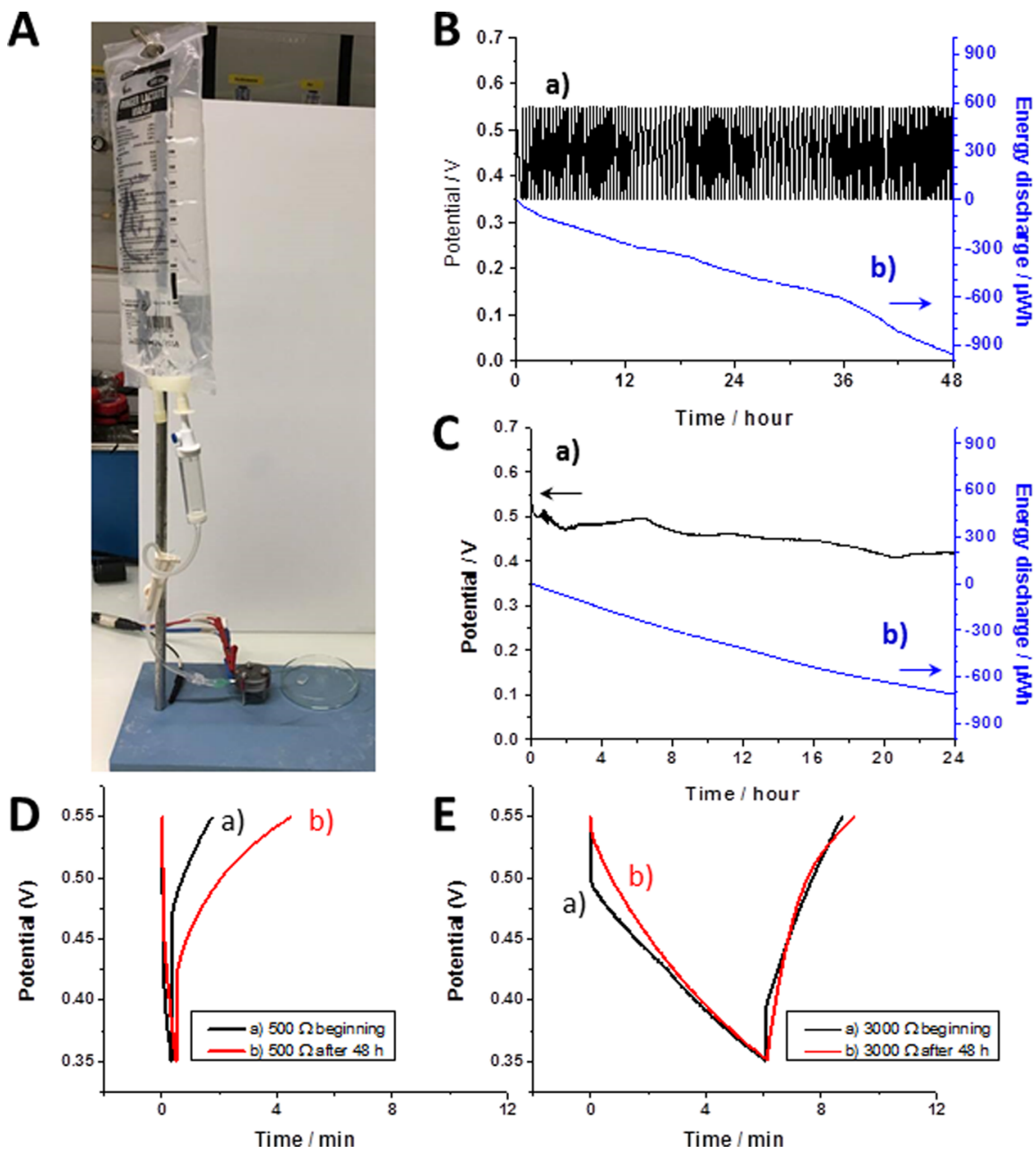

Figure 3. (A) Photograph of the perfusion bag replacing the peristaltic pump for supplying the GBFC with glucose and oxygen. (B) Charge/ discharge cycles between 0.55 and $0.35 \mathrm{~V}$ at $3 \mathrm{k} \Omega$ during $48 \mathrm{~h}$ (a, black) and the produced energy (b, blue); (C) continuous discharge at $6 \mathrm{k} \Omega$ during $24 \mathrm{~h}$ (a, black) and the produced energy (b, blue); (D) discharge/charge cycle time at $500 \Omega$ (a, black) in the beginning and after $48 \mathrm{~h}(\mathrm{~b}$, red); and (E) discharge/charge cycle time at $3 \mathrm{k} \Omega$ (a, black) in the beginning and after $48 \mathrm{~h}$ (b, red).

through design, as compared to configuration $\mathrm{A}$ and $\mathrm{B}$, demonstrates that the flow-through electrolyte maximizes the access of substrates to deeply-CNT-entrapped enzymes. This is not the case for configuration $\mathrm{A}$ and $\mathrm{B}$ where the electrolyte is only in contact with the surface of the CNT electrode.

In spite of the optimized power output with entire wetting and improved glucose/oxygen flow through the pellets, the necessity of the serpentine is an inconvenience of this setup when several GBFCs should be stacked and be connected in parallel or in series. To evaluate the efficiency of our GBFC design for facilitated stacking, while enabling individualized supply of glucose solution, and the possibility for further miniaturization, we fabricated optimized Plexiglas plates as pellet housings in the form of a disc of $36 \mathrm{~mm}$ in diameter, 3 $\mathrm{mm}$ thickness, and with a $13 \mathrm{~mm}$ hole in the center to position each bioelectrode. ${ }^{23}$ A graphoil disc of $36 \mathrm{~mm}$ of diameter is added in each side of the biofuel cell to substitute the graphite plate. A needle was slotted into a drilled hole on the topside of the Plexiglas slice of each bioelectrode to allow complete flowthrough of the air saturated glucose solution from the cathode to the anode with an inlet at the bottom and an outlet at the top of the GBFC (Figure 2, configuration D). This configuration shows slightly better performances than configuration $\mathrm{C}$ since the glucose $/ \mathrm{O}_{2}$ solution passes through the entire CNT-enzyme pellet. However, with the aim to stack several biofuel cells in order to connect them in series or in parallel, configuration $\mathrm{C}$ is more appropriate.

For configuration $\mathrm{D}$, the glucose biofuel cell exhibits an OCV and maximum power output of $0.663 \mathrm{~V}$ and $1.03 \pm 0.05 \mathrm{~mW}$ (at $0.34 \mathrm{~V}$ ). This configuration shows slightly lower performances as compared to configuration $\mathrm{C}$. This likely originates from a more homogeneous supply of electrolyte for configuration $\mathrm{C}$, thanks to the presence of the serpentine design at each electrode. Taking into account the surfaces and volumes of the separating membrane and both electrodes, this performance corresponds to power densities of $0.77 \mathrm{~mW} \mathrm{~cm}^{-2}$, $3.8 \mathrm{~mW} \mathrm{~mL}^{-1}$, and $8.92 \mathrm{~mW} \mathrm{~g}^{-1}$. As a control experiment, we also performed power and polarization curves without any flux of glucose; this configuration exhibiting negligible power output (Figure S2).

These values, obtained at $5 \mathrm{mmol} \mathrm{L}^{-1}$ under air and at $25{ }^{\circ} \mathrm{C}$, are among the best performances for a GBFC operating in vitro. This is close to performances of GBFC based on osmium hydrogels $\left(0.74 \mathrm{~mW} \mathrm{~cm}^{-2} \text { at } 60 \mathrm{mmol} \mathrm{L}^{-1} \text { glucose }\right)^{24}$ or our previously developed GBFC based on CNT pellets $(1.54 \mathrm{~mW}$ $\mathrm{cm}^{-2}$ at $50 \mathrm{mmol} \mathrm{L}^{-1}$ glucose). ${ }^{8,10,25}$

Power Management and Lifetime. In order to examine this setup in more detail, in terms of lifetime and practical 

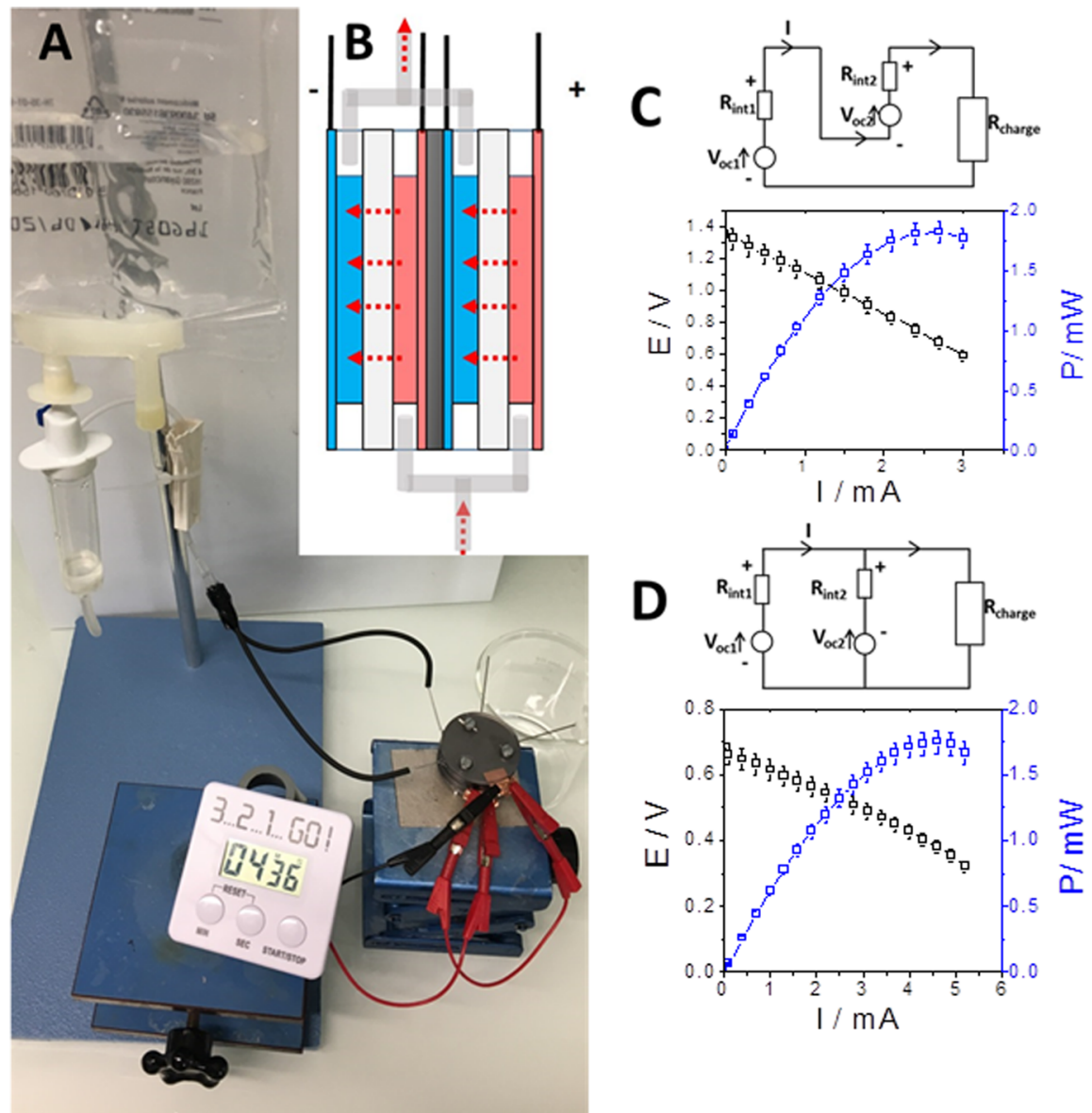

Figure 4. (A) Photograph of two stacked GBFCs connected in series with glucose solution supplied by a perfusion bag and running an electronic timer. (B) Scheme of the flow directions of air saturated $5 \mathrm{mmol} \mathrm{L}^{-1}$ glucose solution for two stacked GBFCs. (C) Applied circuits, corresponding power profile (blue), and polarization curve (black) for the connection of two GBFCs in series (C) and in parallel (D).

power management, two operation modes were applied. The use of a peristaltic pump, of course, nullifies the produced energy by the GBFC. In this context, a perfusion bag containing the glucose solution was mounted to replace the pump (Figure $3 \mathrm{~A})$. Figure $3 \mathrm{~B}$ shows a continuous charge-discharge experiment performed during $24 \mathrm{~h}$. A $3 \mathrm{k} \Omega$ resistance was applied for the discharge from 0.55 to $0.35 \mathrm{~V}$. This voltage range was chosen for reasonable charge/discharge lengths and improved stability of the setup. When the low voltage value of $0.35 \mathrm{~V}$ is reached, the circuit was opened, and the cell voltage was allowed to recharge until the initial $0.55 \mathrm{~V}$ (Figure 3Ba black). During this experiment, almost $3.6 \mathrm{~J}(1 \mathrm{~mW} \mathrm{~h})$ of energy was accumulated in total after $48 \mathrm{~h}$ (Figure $3 \mathrm{Bb}$ blue). At constant discharge with a higher applied resistance of $6 \mathrm{k} \Omega$ (Figure $3 \mathrm{Bc}$ red), the OCV slowly decreased from around $0.5 \mathrm{~V}$ until a plateau was observed at $0.4 \mathrm{~V}$ after $18 \mathrm{~h}$. During the first $24 \mathrm{~h}$, about $2.6 \mathrm{~J}(715 \mu \mathrm{Wh}$ ) could be accumulated (Figure $3 \mathrm{Bd}$ green).

Figure 3C displays a close up of the duration of single charge-discharge cycles at $500 \Omega$ and $3 \mathrm{k} \Omega$, at the beginning of the experiment and $48 \mathrm{~h}$ later. In addition, a charge-discharge cycle was recorded after $200 \mathrm{~h}$ for the $3 \mathrm{k} \Omega$ discharge experiment (data not shown). For the $500 \Omega$ discharges, the charge/discharge cycle is quite fast and less than $2 \mathrm{~min}$ in the beginning. However, the cycle time increases quite fast until more than $4 \mathrm{~min}$ per cycle is required after $48 \mathrm{~h}$. When a $3 \mathrm{k} \Omega$ discharge is applied, the time of a single charge/discharge cycle of around $9 \mathrm{~min}$ remains constant during $48 \mathrm{~h}$. Since mass transport limitations for this flow setup can be excluded, this increasing cycle time has to be correlated to the reduced electron transfer rates due to the loss of the enzymes' and/or mediators' activity. This indicates that the enzymes lose their activity faster at discharges close to the maximum power output. It is therefore conclusive that during $48 \mathrm{~h}, 2$ times more energy ( $3.6 \mathrm{~J} ; 1 \mathrm{~mW} \mathrm{~h}$ ) could be accumulated at $3 \mathrm{k} \Omega$ discharges than at $500 \Omega$ discharges $(1.8 \mathrm{~J} ; 0.5 \mathrm{~mW} \mathrm{~h})$.

It appears to be more appropriate to discharge continuously when high power is required over a short time while discharge/ charge cycles are better for prolonging GBFC lifetime and achieving higher energy yields. To obtain effective energy yields, a perfusion bag containing the glucose solution was mounted to replace the peristaltic pump (Figure 3A). Almost similar performances were observed with this setup which produced $3.6 \mathrm{~J}(1 \mathrm{mWh})$ of effective energy after $48 \mathrm{~h}$ under discharge/charge cycle mode at $3 \mathrm{k} \Omega$.

Assembly of Two Glucose Biofuel Cells. The circuits used for connecting two stacked GBFCs in series and in parallel are displayed in Figure 4C,D, respectively. Separated inserts were used to supply the bioelectrodes with the air saturated glucose solution while the flow direction was still directed from the cathode to the anode as shown in Figure 4B. The same physiologically relevant $5 \mathrm{mmol} \mathrm{\textrm {L } ^ { - 1 }}$ glucose solution was used to supply both GBFCs and was simply separated by T-pieces. Figure $4 \mathrm{C}$ shows the polarization and power curves for the 
system in series. The power curve was plotted from the polarization curve, which was recorded by successive $30 \mathrm{~s}$ discharges at constant current $(0.1 \mathrm{~mA}$ to $5.2 \mathrm{~mA})$. The performances were recorded at $\mathrm{pH} 7$ in the presence of a 5 mmol L $\mathrm{L}^{-1}$ air saturated glucose solution flux. For the parallel circuit, the OCV remained constant $(0.669 \mathrm{~V})$ while the maximum power output of $1.75 \pm 0.09 \mathrm{~mW}$ at $0.381 \mathrm{~V}$ and current $(4.6 \mathrm{~mA})$ increased by a factor of 2 compared to one individual GBFC. The stacked glucose biofuel cell in series (Figure 4C) exhibits an $\mathrm{OCV}$ of $1.35 \mathrm{~V}$ and a maximum power output of $1.82 \pm 0.09 \mathrm{~mW}$ (at $0.675 \mathrm{~V}$ ). Also for the GBFC in series, the generated power and the operational potential is almost two times higher than that observed for one individual GBFC, while the current remains the same. This scholastic doubling of cell voltage and current for the connection of two GBFCs, respectively, in series and in parallel, demonstrates the appropriateness of our design for efficient stacking and supply of glucose solution in order to connect several GBFCs in miniaturizable housings without a loss of performance. To demonstrate practical device powering, an electronic timer was run for $17 \mathrm{~h}$, supplied by only two GBFCs connected in series, and without the need for a step up converter or a capacitor (Figure 4A). The OCV of this device remained almost stable and decreased from 1.37 to $1.32 \mathrm{~V}$ during the whole experiment (Figure S3).

\section{CONCLUSIONS}

A new design of a glucose biofuel cell is presented allowing the stacking of two GBFCs and their connection in parallel and in series. Each cell is supplied by an individual air saturated glucose flow which is directed from the cathode through a cellulose membrane to the anode. Under continuous discharge, one individual GBFC generated $2.5 \mathrm{~J}(0.7 \mathrm{~mW} \mathrm{~h})$ of power using an air saturated $5 \mathrm{mmol} \mathrm{L}^{-1}$ glucose solution in $24 \mathrm{~h}$. Under charge-discharge conditions, this biofuel cell was stable over 9 days and produced $7.9 \mathrm{~J}(2.2 \mathrm{~mW} \mathrm{~h})$. Two stacked biofuel cells provided an almost 2-fold power output when connected either in series or in parallel. The obtained power densities with our stacked GBFC design are comparable to the best performances in the literature ${ }^{17,18}$ but the energy yields largely overpass the vast majority of reported performances. Finally, a portable demonstrator device could be operated for $17 \mathrm{~h}$ with two GBFCs in series. The stacking and connection of further GBFCs is currently being evaluated. This flow setup represents a step forward toward realistic applications for powering portable or biomedical electronic devices, addressing both voltage and current limitations. The only remaining drawback is the lifetime under continuous operation. Even when our design shows enhanced performances, these power generators can at this stage be envisioned for short-term use devices.

\section{ASSOCIATED CONTENT}

\section{S Supporting Information}

This material is free of charge via the Internet at The Supporting Information is available free of charge on the ACS Publications website at DOI: 10.1021/acsami.7b06717.

Figures of CV scans, control experiments, and cell voltage evolution over time (PDF)

\section{AUTHOR INFORMATION}

\section{Corresponding Authors}

*E-mail: alan.le-goff@univ-grenoble-alpes.fr (A.L.G.).

*E-mail: michael.holzinger@univ-grenoble-alpes.fr (M.H.).

\section{ORCID}

Michael Holzinger: 0000-0003-3700-4673

\section{Author Contributions}

The manuscript was written through contributions of all authors. All authors have given approval to the final version of the manuscript.

Notes

The authors declare no competing financial interest.

\section{ACKNOWLEDGMENTS}

The region Auvergne-Rhône-Alpes is acknowledged for the $\mathrm{PhD}$ funding (no.: 14-011164-01) of C.A. The authors would also like to thank the mechanical team of LiPhy at Grenoble for the fabrication of the PTFE and Plexiglas plates. The authors wish further to acknowledge the support from the platform Chimie NanoBio ICMG FR 2607 (PCN-ICMG), from the Institute Carnot PolyNat at Grenoble, and from the LabEx ARCANE (ANR-11-LABX-0003-01).

\section{REFERENCES}

(1) Marx, N.; Hissel, D.; Gustin, F.; Boulon, L.; Agbossou, K. On the sizing and energy management of an Hybrid Multistack Fuel Cell Battery System for Automotive Applications. Int. J. Hydrogen Energy 2017, 42 (2), 1518-1526.

(2) Durbin, D. J.; Malardier-Jugroot, C. Review of Hydrogen Storage Techniques for on Board Vehicle Applications. Int. J. Hydrogen Energy 2013, 38 (34), 14595-14617.

(3) Santiago, Ó.; Navarro, E.; Raso, M. A.; Leo, T. J. Review of Implantable and External Abiotically Catalysed Glucose Fuel Cells and the Differences between their Membranes and Catalysts. Appl. Energy 2016, 179, 497-522.

(4) Elouarzaki, K.; Le Goff, A.; Holzinger, M.; Thery, J.; Cosnier, S. Electrocatalytic oxidation of Glucose by Rhodium Porphyrin-functionalized MWCNT Electrodes: Application to a fully molecular Catalystbased Glucose $/ \mathrm{O}_{2}$ Fuel Cell. J. Am. Chem. Soc. 2012, 134 (34), 14078-14085.

(5) Minteer, S. D.; Liaw, B. Y.; Cooney, M. J. Enzyme-based Biofuel Cells. Curr. Opin. Biotechnol. 2007, 18 (3), 228-234.

(6) Ferri, S.; Kojima, K.; Sode, K. Review of Glucose Oxidases and Glucose Dehydrogenases: A Bird's Eye View of Glucose Sensing Enzymes. J. Diabetes Sci. Technol. 2011, 5 (5), 1068-1076.

(7) Gregg, B. A.; Heller, A. Redox Polymer Films containing Enzymes. 2. Glucose oxidase containing enzyme electrodes. J. Phys. Chem. 1991, 95 (15), 5976-5980.

(8) Reuillard, B.; Le Goff, A.; Agnès, C.; Holzinger, M.; Zebda, A.; Gondran, C.; Elouarzaki, K.; Cosnier, S. High power Enzymatic Biofuel Cell based on Naphtoquinone-mediated oxidation of Glucose by Glucose oxidase in a Carbon Nanotube 3D matrix. Phys. Chem. Chem. Phys. 2013, 15 (14), 4892-4896.

(9) Milton, R. D.; Hickey, D. P.; Abdellaoui, S.; Lim, K.; Wu, F.; Tan, B.; Minteer, S. D. Rational design of Quinones for High Power Density Biofuel Cells. Chem. Sci. 2015, 6 (8), 4867-4875.

(10) Zebda, A.; Gondran, C.; Le Goff, A.; Holzinger, M.; Cinquin, P.; Cosnier, S. Mediatorless high-power Glucose Biofuel Cells based on compressed Carbon Nanotube-Enzyme Electrodes. Nat. Commun. 2011, 2, 370.

(11) Le Goff, A.; Holzinger, M.; Cosnier, S. Recent Progress in Oxygen-Reducing Laccase Biocathodes for Enzymatic Biofuel Cells. Cell. Mol. Life Sci. 2015, 72 (5), 941-952.

(12) Lalaoui, N.; Le Goff, A.; Holzinger, M.; Cosnier, S. Fully Oriented Bilirubin Oxidase on Porphyrin-Functionalized Carbon 
Nanotube Electrodes for Electrocatalytic Oxygen Reduction. Chem. Eur. J. 2015, 21 (47), 16868-16873.

(13) Lalaoui, N.; Holzinger, M.; Le Goff, A.; Cosnier, S. Diazonium Functionalisation of Carbon Nanotubes for Specific Orientation of Multicopper Oxidases: Controlling Electron Entry Points and Oxygen Diffusion to the Enzyme. Chem. - Eur. J. 2016, 22 (30), 10494-10500.

(14) Cosnier, S.; Le Goff, A.; Holzinger, M. Towards Glucose Biofuel cells implanted in Human Body for powering Artificial Organs: Review. Electrochem. Commun. 2014, 38, 19-23.

(15) Szczupak, A.; Halámek, J.; Halámková, L.; Bocharova, V.; Alfonta, L.; Katz, E. Living Battery - Biofuel Cells operating in vivo in Clams. Energy Environ. Sci. 2012, 5 (10), 8891-8895.

(16) MacVittie, K.; Halamek, J.; Halamkova, L.; Southcott, M.; Jemison, W. D.; Lobel, R.; Katz, E. From "Cyborg" Lobsters to a Pacemaker Powered by Implantable Biofuel Cells. Energy Environ. Sci. 2013, 6 (1), 81-86.

(17) Sakai, H.; Nakagawa, T.; Mita, H.; Kumita, H.; Tokita, Y. Evolution of Sony's Biofuel Cell. Meeting Abstracts 2010, No. 6, 396396.

(18) Miyake, T.; Haneda, K.; Yoshino, S.; Nishizawa, M. Flexible, layered Biofuel Cells. Biosens. Bioelectron. 2013, 40 (1), 45-49.

(19) Reid, R. C.; Giroud, F.; Minteer, S. D.; Gale, B. K. Enzymatic Biofuel Cell with a Flow-through Toray Paper Bioanode for Improved Fuel Utilization. J. Electrochem. Soc. 2013, 160 (9), H612-H619.

(20) Rincón, R. A.; Lau, C.; Luckarift, H. R.; Garcia, K. E.; Adkins, E.; Johnson, G. R.; Atanassov, P. Enzymatic Fuel Cells: Integrating flowthrough Anode and air-breathing Cathode into a Membrane-less Biofuel Cell Design. Biosens. Bioelectron. 2011, 27 (1), 132-136.

(21) Rincón, R. A.; Lau, C.; Garcia, K. E.; Atanassov, P. Flow-through 3D Biofuel Cell Anode for NAD+-dependent Enzymes. Electrochim. Acta 2011, 56 (5), 2503-2509.

(22) du Toit, H.; Di Lorenzo, M. Continuous Power generation from Glucose with two different Miniature Flow-Through Enzymatic Biofuel Cells. Biosens. Bioelectron. 2015, 69, 199-205.

(23) Le Goff, A.; Nedellec, Y.; Abreu, C.; Cosnier, S.; Holzinger, M. Pile à Biocombustible. F064400385/FR/BN, CNRS, France 2017.

(24) Gao, F.; Viry, L.; Maugey, M.; Poulin, P.; Mano, N. Engineering Hybrid Nanotube wires for high-power Biofuel Cells. Nat. Commun. 2010, 1 (1), 1-7.

(25) Reuillard, B.; Abreu, C.; Lalaoui, N.; Le Goff, A.; Holzinger, M.; Ondel, O.; Buret, F.; Cosnier, S. One-year Stability for a Glucose/ Oxygen Biofuel cell combined with $\mathrm{pH}$ Reactivation of the Laccase/ Carbon Nanotube Biocathode. Bioelectrochemistry 2015, 106 (A), 7376. 